\title{
Pengembangan Media Pembelajaran Lectora Inspire pada Tema 3 Subtema 7 dengan Penguatan Karakter Rasa Ingin Tahu Kelas IV SDN Karangtengah 1 Kota Blitar
}

\author{
Hanik Fitrotul Amilia*, Sumanto, Esti Untari \\ Universitas Negeri Malang, Jl. Semarang No. 5 Malang, Jawa Timur, Indonesia \\ *Penulis korespondensi, Surel: hanikfitamilia06@gmail.com
}

Paper received: 3-3-2021; revised: 24-3-2021; accepted: 28-3-2021

\begin{abstract}
Lectora Inspire learning media is an application that contains information or material, images, animations, games, and videos that are packaged practically and interestingly so that it can make students more enthusiastic in the learning process. the purpose of this research and development is to test the feasibility of Lectora inspire media in terms of validity, practicality, and attractiveness. The method used is Borg and Gall with 10 steps of research. The results of research and development show that Lectora Inspire learning media from material experts is 91.6 percent, from media experts is 91.6 percent, user rating (practitioners) is 94.4 percent, so it can be said that Lectora Inspire learning media is very valid for use. The results of the student response questionnaire were 95.8 percent so it can be said that Lectora Inspire learning media is very interesting and practical to use.
\end{abstract}

Keywords: lectora inspire; curiosity

\begin{abstract}
Abstrak
Media pembelajaran Lectora Inspire sebuah aplikasi yang memuat suatu informasi atau materi, gambar, animasi, game maupun video dikemas secara praktis dan menarik sehingga dapat membuat siswa lebih antusias dalam proses pembelajaran. tujuan penelitian dan pengembangan ini untuk menguji kelayakan media lectora inspire dari segi kevalidan, kepraktisan, dan kemenarikan. Metode yang digunakan adalah Borg and Gall dengan 10 langkah penelitian. Hasil penelitian dan pengembangan menunjukkan bahwa media pembelajaran Lectora Inspire dari ahli materi sebesar 91,6 persen, dari ahli media sebesar 91,6 persen, penilaian pengguna (praktisi) sebesar 94,4 persen, sehingga dapat dikatakan bahwa media pembelajaran Lectora Inspire sangat valid untuk digunakan. Hasil angket respon siswa sebesar 95,8 persen sehingga dapat dikatakan bahwa media pembelajaran Lectora Inspire sangat menarik dan praktis untuk digunakan.
\end{abstract}

Kata kunci: lectora inspire; rasa ingin tahu

\section{Pendahuluan}

Media pembelajaran adalah segala sesuatu yang dapat menyalurkan pesan, dapat merangsang pikiran, perasaan, perhatian, dan minat siswa, sehingga dapat mendorong terciptanya proses belajar pada diri siswa. Sutirman (Shalikhah, 2017) menyatakan bahwa media pembelajaran dikatakan sebagai alat-alat grafis, photografis atau elektronis, yang dapat digunakan untuk menangkap, memproses, dan menyusun kembali informasi visual atau verbal. Salah satu media pembelajaran yang dapat digunakan guru dengan memanfaatkan teknologi informasi dan komunikasi (TIK) salah satu contohnya adalah media pembealajaran menggunakan Lectora Inspire. Mas'ud (2014) menyatakan bahwa Lectora Inspire adalah Authoring Tool untuk pengembangan konten e-learning yang dikembangkan oleh Trivanantis Corporation. Lectora Inspire mampu membuat kursus online cepat dan sederhana. Pendirinya adalah Thimothy D. Loudermilk di Cincinnati, Ohio, Amerika tahun 1999. 
Kegiatan pembelajaran mengacu pada Kurikulum 2013 sebagai perangkat perencanaan proses pembelajaran. Implementasi kurikulum 2013 membutuhkan perubahan paradigma pembelajaran dari pembelajaran konvensional yang hanya dilakukan di dalam kelas, menjadi pembelajaran yang mengaktifkan siswa untuk menggunakan aneka sumber belajar yang dapat diperoleh diluar kelas. Kurikulum 2013 dikembangkan dalam rangka perkembangan teknologi, menjawab tantangan perubahan zaman, dan kebutuhan siswa dengan menanamkan nilai-nilai moral dan karakter bangsa. Membangun karakter pada diri siswa dimulai dari sedini mungkin sehingga perilaku yang diharapkan akan terbentuk pada siswa dengan adanya pendidikan karakter. Salah satu penanaman karakter pada kurikulum 2013 bisa melalui penggunaan media pembelajaran. Karakter rasa rasa ingin tahu merupakan salah satu dari 18 karakter yang harus ada di dalam proses pendidikan. Pemilihan karakter rasa ingin tahu bertujuan agar siswa selalu berupaya dalam mengetahui materi, media dan kegiatan pembelajaran yang sesuai dengan perkembangan teknologi tanpa mengkesampingkan pendidikan karakter bangsa indonesia.

Sekolah Dasar Negeri Karangtengah 1 merupakan salah satu sekolah dasar di Kota Blitar yang menerapkan kurikulum 2013 sebagai pedoman sistem pembelajaran. Berdasarkan hasil wawancara yang dilakukan bersama guru kelas IV di SDN Karangtengah 1 pada hari selasa tanggal 10 desember 2019, diperoleh informasi bahwa sekolah tidak memliki media pembelajaran yang memadai, khususnya pada tema "Indahnya Keragaman di Negeriku" subtema "Indahnya Persatuan dan Kesatuan Negeriku". Proses pembelajaran di kelas IVB sejauh ini berjalan dengan baik dan lancar dengan menggunakan metode ceramah, percobaan, penugasan, bermain peran, tanya jawab, dan diskusi. Metode yang digunakan guru menyesuaikan pada jenis materi yang akan dipelajari bersama siswa. Di SDN Karangtengah 1 Kota Blitar memiliki 2 rombongan belajar di tiap kelasnya.

Materi yang dirasa sulit berdasarkan hasil wawancara dengan guru kelas IV adalah mata pelajaran IPS khususnya Tema 7 "Indahnya Keragaman di Negeriku" subtema 3 "Indahnya Persatuan dan Kesatuan Negeriku" karena sumber belajar hanya dari buku siswa dan buku pegangangan untuk guru. Proses pembelajaran pada pengalaman tahun lalu khususnya pada materi keragaman ekonomi dilakukan hanya dengan siswa membaca teks dan mendengarkan penjelasan dari guru sehingga siswa cepat merasa bosan. Guru kelas IVB menyarankan untuk membuat media pembelajaran yang dapat memanfaatkan lab komputer sekolah, karena ketersediaan fasilitas lab komputer sejak lama namun belum dimanfaatkan secara optimal.

Guru kelas IVB pernah menggunakan lab komputer dalam kegiatan evaluasi akan tetapi hasilnya kurang memuaskan bahkan lebih buruk hasilnya dari kegitan evaluasi dengan cara manual. Sehingga dari hasil penelitian dan permasalahan yang ada di kelas IVB SDN Karangtengah 1 Kota Blitar dapat memberikan sebuah ide bagi peneliti untuk mengembangkan media pembelajaran yang dapat menfaatkan lab komputer sesuai dengan permintaan guru kelas IV, Pemilihan Media Pembelajaran Lectora Inspire yang akan dikembangkan untuk mengulas muatan IPS dan Bahasa Indoensia yang dimuat dalam Tema 7 "Indahnya Keragaman di Negeriku" subtema 3 "Indahnya Persatuan dan Kesatuan Negeriku". Pembelajaran 3 \& 4. Dalam pembelajaran ini, siswa mempelajari materi keragaman ekonomi dan menggali informasi penting dalam teks yang cangkupannya terlalu luas jika hanya dijelaskan dengan metode ceramah saja, oleh karena itu diperlukan adanya visualisasi menggunakan media 
pembelajaran agar konsep yang abstrak seolah-olah terlihat seperti nyata. Penggunaan Lectora Inspire dirasa sangat cocok digunakan karena Lectora Inspire memiliki konten yang berisi teks, gambar, suara, animasi, video, game dan evaluasi yang dapat memudahkan guru dalam melakukan penilaian. Lectora Inspire lebih baik dibandingkan Powerpoint, bahkan Powerpoint dapat dimasukkan kedalamnya. Pemilihan Lectora Inspire didasari juga dengan hasil penelitian yang dilakukan oleh Astuti pada tahun 2018 bahwa kelayakan kualitas media ditunjukkan dari hasil penilaian produk menggunakan skala lima oleh ahli media dan guru dengan kategori penilaian sangat baik rata-rata skor 4,3.

Berdasarkan uraian yang telah dikemukakan, maka perlu dilakukan penelitian dengan judul " Pengembangan Media Pembelajaran Lectora Inspire pada Tema 7 Sutema 3 Dengan Penguatan Karakter Rasa Ingin Tahu Kelas IV SDN Karangtengah 1 Kota Blitar".

\section{Metode}

Dalam mengembangkan media pembelajaran Lectora Inspire menggunakan metode R \& D (Research and Development), yang mengacu pada model pengembangan Borg \& Gall. Model pengembangan Borg \& Gall menurut Sugiyono (2015:409) memiliki 10 tahapan proses yang dilakukan, yaitu : 1) potensi masalah, 2) pengumpulan data, 3) desain produk, 4) validasi produk, 5) revisi produk, 6) uji coba tahap 1, 7) revisi produk, 8) uji coba tahap 2,9 ) revisi produk, dan 10) produksi massal.

Sumber data dalam penelitian dan pengembangan ini diperoleh melalui hasil angket validasi materi, ahli media, pengguna/ guru, dan angket respon siswa. Pemilihan validator materi adalah ahli materi yang berkompeten, validator media adalah ahli media yang berkompenten, dan validator pengguna adalah guru kelas IV SDN Karangtengah 1 Kota Blitar. Subjek uji coba tahap 1 adalah siswa kelas IVA SDN Karangtengah 1 Kota Blitar sebanyak 6 anak dan subjek uji coba tahap 2 adalah siswa kelas IVB SDN Karangtengah 1 Kota Blitar sebanyak 30 anak.

Teknik pengumpulan data yang digunakan adalah wawancara dan angket/ kusioner. Wawancara dilakukan pada awal penelitian untuk mengetahui permasalahan yang terjadi dilapangan. Angket digunakan untuk mengetahui kelayakan penggunaan media pembelajaran Lectora Inspire dalam proses pembelajaran berdasarkan ahli materi, media, dan pengguna/ guru, dan angket siswa untuk mengetahui respon siswa terhadap produk yang dikembangkan.

Teknik analisis data yang digunakan adalah teknik kualitatif dan teknik kuantitatif. Teknik analisis data untuk uji kevalidan produk menggunakan data yang diperoleh melalui instrument pengumpulkan data, dianalisis dengan rumus sebagai berikut.

Validasi $=\frac{T s e}{T s h} \times 100 \%$

Keterangan :

Vah = validasi asli

Tse $=$ total skor empirik yang dicapai 
Tsh = total skor empirik yang diharapkan

Hasil perhitungan dalam bentuk presentase untuk selanjutnya dapat dimaknai seperti dalam tabel kriteria kategorisasi hasil validasi berikut.

Tabel 1. Kriteria kategorisasi hasil validasi

\begin{tabular}{lll}
\hline \multicolumn{1}{c}{ Kriteria } & \multicolumn{1}{c}{ Tingkat Valid } & \multicolumn{1}{c}{ Keterangan } \\
\hline $85,01-100,00$ & Sangat valid & Dapat digunakan tanpa revisi \\
$70,01-85,00$ & Cukup Valid & Dapat digunakan dengan revisi kecil \\
$50,01-70,00$ & Kurang valid & Boleh digunakan dengan revisi besar \\
$01,00-50,00$ & Sangat tidak valid & Tidak boleh digunakan \\
\hline
\end{tabular}

Selanjutnya hasil angket respon siswa dapat dianalisis menggunakan rumus Yamasari (dalam Santoso, dkk., 2016) berikut.

$$
P=\frac{X i}{X \max } \times 100 \%
$$

Keterangan:

$$
\begin{array}{ll}
\mathrm{P} & =\text { Presentase skor } \\
\mathrm{Xi} & =\text { Jumlah skor yang dipilih } \\
\mathrm{N} & =\text { Jumlah skor maksimal }
\end{array}
$$

Selanjutnya hasil perhitungan presentase dari masing-masing responden dimaknai dalam tabel 2 yang bersumber dari Yamasari (dalam Susanto, 2016) berikut ini

Tabel 2. Kriteria Kategorisasi Hasil

\begin{tabular}{cc}
\hline Tingkat pencapaian (\%) & Kategori \\
\hline $76 \leq \mathrm{P} \leq 100$ & Sangat praktis \\
$51 \leq \mathrm{P} \leq 75$ & Praktis \\
$26 \leq \mathrm{P} \leq 50$ & Kurang praktis \\
$0 \leq \mathrm{P} \leq 20$ & Tidak praktis \\
\hline
\end{tabular}

\section{Hasil dan Pembahasan}

\subsection{Hasil}

Hasil penelitian terdiri dari dua data yaitu data hasil validasi para ahli dan data hasil uji coba. Penyajian dan hasil validasi dipaparkan berdasarkan validasi ahli materi, ahli media, dan validasi pengguna (guru). Data yang diperoleh dari hasil validasi meliputi data kuantitatif atau berupa angka dari hasil penilaian instrumen lembar validasi, dan data kualitatif yang berupa kritik atau saran dari validator.

\subsubsection{Analisis Data Validasi Materi}

Pada aspek kelayakan isi mendapatkan skor 11, aspek penyajian materi mendapatkan skor 4, dan aspek bahasa 7. Total skor pada semua aspek yang didapat dari validasi ahli materi sebesar 22 dari total maksimal 24. 
Hasil perhitungan presentase kevalidan dari hasil ahli materi sebagai berikut:

Validasi $=\frac{T s e}{T s h} \times 100 \%$

Validasi $=\frac{22}{24} \times 100 \%=91,6 \%$

Hasil perhitungan dapat diinteprestasi berdasarkan kriteria dari Akbar (2015: 82) dalam kriteria kategorisasi hasil validasi presentase sebesar 91,6\% termasuk kedalam tingkat pencapaian interval 85,01\% -100,00\% yang dinyatakan sangat valid, media Lectora Inspire ini dapat digunakan dengan revisi kecil.

\subsubsection{Analisis Data Validasi Media}

Pada aspek kelayakan penyajian desain mendapatkan skor 11 dari total skor maksimal 12, dari masing kriteria penyajian mendapat skor 4, kriteria kepraktisan 3 dan kriteria 4.

Hasil perhitungan presentase kevalidan dari hasil ahli materi sebagai berikut:

Validasi $=\frac{T s e}{T s h} \times 100 \%$

Validasi $=\frac{11}{12} \times 100 \%=91,6 \%$

Hasil perhitungan dapat diinteprestasi berdasarkan kriteria dari Akbar (2015: 82) dalam kriteria kategorisasi hasil validasi presentase sebesar 91,6\% termasuk kedalam tingkat pencapaian interval $85,01 \%-100,00 \%$ yang dinyatakan sangat valid, media Lectora Inspire ini dapat digunakan dengan revisi kecil.

\subsubsection{Analisis Data Validasi Pengguna/Guru}

Pada aspek kelayakan isi mendapatkan skor 12, aspek penyajian materi mendapatkan skor 4, aspek bahasa 7, aspek kelayakan penyajian desain 11 . Total skor pada semua aspek yang didapat dari validasi ahli materi sebesar 34 dari total maksimal 36.

Hasil perhitungan presentase kevalidan dari hasil pengguna/guru sebagai berikut:

Validasi $=\frac{T s e}{T s h} \times 100 \%$

Validasi $=\frac{34}{36} \times 100 \%=94,4 \%$

Hasil perhitungan dapat diinteprestasi berdasarkan kriteria dari Akbar (2015: 82) dalam kriteria kategorisasi hasil validasi presentase sebesar 94,4\% termasuk kedalam tingkat pencapaian interval $85,01 \%-100,00 \%$ yang dinyatakan sangat valid, media Lectora Inspire ini dapat digunakan dengan revisi kecil. 


\subsubsection{Analisis Data Hasil Uji Coba}

\subsubsection{Uji Coba Lapangan 1}

Uji coba lapangan tahap pertama media pembelajaran Lectora Inspire ini dilakukan di kelas IVA SDN Karangtengah 1 kota Blitar pada tanggal 25 Februari 2020 dengan subjek 6 siswa kelas IV yang mewakili tingkat prestasi belajar tinggi, sedang, dan rendah. Uji coba lapangan tahap pertama ini menilai kemenarikan dan kepraktisan media dan meminimalisir kesalahan media sebelum diuji coba lapangan tahap kedua. Hasil angket uji coba lapangan 1 secara keseluruhan 98,3\% menjawab "ya" dan 1,7\% menjawab "tidak". Sehingga dalam kategorisasi hasil termasuk kedalam rentang $76 \leq \mathrm{P} \leq 100 \%$ dengan kategori sangat praktis, menarik dengan pengutan karakter rasa ingin tahu dan dapat digunakan dalam pembelajaran.

\subsubsection{Uji Coba Lapangan 2}

Uji coba lapangan tahap kedua media pembelajaran Lectora Inspire ini dilakukan di kelas IVB SDN Karangtengah 1 kota Blitar pada tanggal 26-27 Februari 2020 dengan subjek 30 siswa. Uji coba lapangan tahap kedua ini menilai kemenarikan dan kepraktisan media dengan pengutan karakter rasa ingin tahu. Hasil angket uji coba lapangan 2 secara keseluruhan 93,3\% menjawab "ya" dan 6,7\% menjawab "tidak". Sehingga dalam kategorisasi hasil termasuk kedalam rentang $76 \leq \mathrm{P} \leq 100 \%$ dengan kategori sangat praktis, menarik dengan pengutan karakter rasa ingin tahu dan dapat digunakan dalam pembelajaran.

\subsection{Pembahasan}

Lectora Inspire adalah sebuah aplikasi (software) yang dapat digunakan guru untuk memuat suatu informasi atau materi, gambar, animasi, game maupun video yang dikemas secara praktis dan menarik sehingga dapat membuat siswa lebih antusias dalam proses pembelajaran. Media ini mengulas materi tematik Tema 7 "Indahnya Keragaman di Negeriku" Subtema 3 "Indahnya Persatuan dan Kesatuan Negeriku pembelajaran 3 \& 4. Didalamnya akan dikembangkan muatan Bahasa Indonesia dan Ilmu Pengetahuan Sosial. Media pembelajaran dapat disebarluaskan secara offline melalui CD-Drive dengan disertai buku petunjuk.

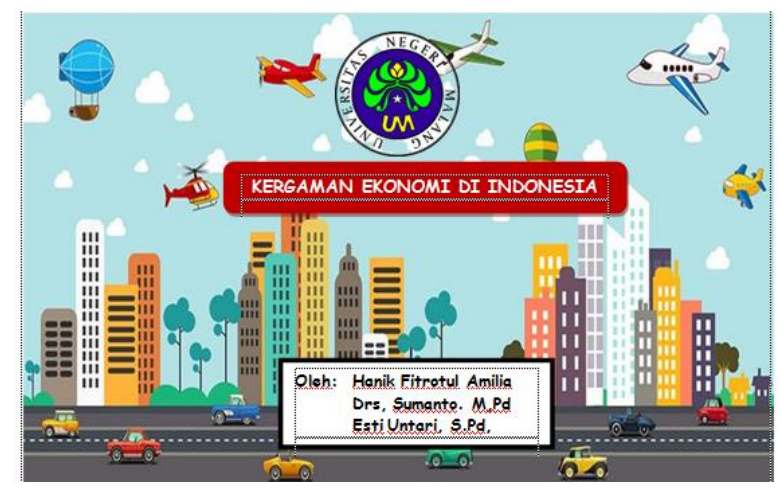

Gambar 1. produk media 


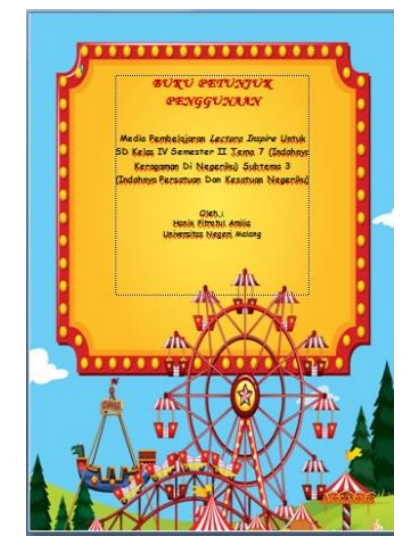

\section{Gambar 2. Buku petunjuk pengguna}

Respons siswa dengan adanya produk media pembelajaran ini sangat positif. Siswa kelas IVB SDN Karangtenagah 1 kota Blitar yang berjumlah 30 anak sangat antusias mengikuti pembelajaran dengan menggunakan komputer. Pada saat pembelajaran, dengan semangat semua siswa mempelajari bagian demi bagian dari materi keragaman ekonomi, siswa juga mudah mengingat materi yang disampaikan, hal ini terlihat ketika ada proses tanya jawab saat pembelajaran berlangsung. Rasa ingin tahu siswa juga terlihat ketika mereka memilih tomboltombol yang ada dalam media pembelajaran Lectora Inspire dibuktikan dengan siswa belajar lebih lanjut membaca dan memperhatikan setiap video. Semua siswa bersemangat pada saat pembelajaran dikarenakan gambar, ilustrasi, dan video yang ada di media membantu kemampuan berpikir dan bernalar.

Berdasarkan kajian yang telah dijabarkan media pembelajaran Lectora Inspire ini memiliki beberapa kelebihan dan kekurangan. Berikut ini kelebihan media pembelajaran Lectora Inspire antara lain: 1) media mudah untuk di copy-paste pada PC atau laptop, 2) media mudah di digunakaan siswa karena terdapat tombol yang jelas, 3) media bersifat interaktif sehingga siswa terlibat langsung dalam pembelajaran dan membuat pembelajaran lebih bermakna, 4) media interaktif berisikan teks, gambar ilustrasi, audio, video, dan warna yang beragam sehingga memacu semangat siswa untuk belajar, dan (5) siswa merasa senang dan tertarik untuk belajar, sehingga media interaktif ini dapat mendorong siswa belajar lebih lanjut lagi.

Selain memiliki kelebihan produk media interaktif, juga memiliki kekurangan sebagai berikut ini: 1) media pembelajaran Lectora Inspire membutuhkan saran dan prasaran sekolah yang memadai seperti listrik, proyektor, dan komputer/laptop, 2) desian yang rumit dan membutuhkan waktu yang lumayan lama dalam proses pembuatan, dan 3) kendalanya jika listrik padam, maka media interaktif tidak dapat digunkan.

Pengembangan media pembelajaran Lectora Inspire interaktif divalidasi oleh ahli materi, ahli media dan pengguna. Data hasil validasi disajikan sebagai berikut. 
Tabel 3. Persentase Hasil Validasi Ahli

\begin{tabular}{llll}
\hline No & Validator & Persentase & Kriteria \\
\hline 1. & Ahli materi & $91,6 \%$ & Sangat valid \\
2. & Ahli media & $91,6 \%$ & Sangat valid \\
3. & Pengguna & $94,4 \%$ & Sangat valid \\
\hline Rata-rata & $92,5 \%$ & Sangat valid \\
\hline
\end{tabular}

\subsubsection{Validasi Ahli Materi}

Validasi ahli materi meliputi penilaian aspek kelayakan isi, penyajian materi, dan bahasa. Berdasarkan perhitungan yang telah dilakukan dari segi materi, kevalidan media pembelajaran Lectora Inspire sebesar 91,6\%. Maka persentase ini masuk ke dalam rentang 85,01\% $100,00 \%$, jika di interpretasikan maka hasilnya sangat valid, tidak memerlukan revisi ketika digunakan. Hasil validasi materi ini sudah cukup baik, karena sebelumnya, Sukamto \& Wardani (2016) mengembangkan media Lectora Inspire pada pembelajaran matematika hanya tervalidasi rata-rata $78,79 \%$ dari ahli materi.

Namun untuk penyempurnaan media ini terdapat beberapa saran perbaikan dari validator materi antara lain mengubah kata "petani dibedakan menurut jenis usahanya yang meliputi petani sawah dan petani perkebunan" menjadi "petani Indonesia melakukan 2 jenis kegiatan usaha dibidang pertanian yaitu petani tradisional dan petan modern" Kata-kata tersebut diperbaiki agar mengandung komunikasi sosial, hal ini sejalan dengan pendapat Siska (2016: 7), Ilmu pengetahuan sosial merupakan program pendidikan atau bidang studi dalam kurikulum sekolah yang memepelajari kehidupan manusia dalam masyarakat serta hubungan atau interaksi antara manusia dengan lingkungannya (fisik dan sosial) Selain itu, validator materi juga menyarankan dalam menyusun media pembelarajaran harus menyesuaikan tujuan, indikator dan materi dengan Kompetensi Inti (KI) dan Kompetensi Dasar (KD). Kesesuaian media dengan materi juga didasarkan atas teori yang dikemukakan oleh Gerlach dan Elly (dalam Setyosari dan Sihkabuden, 2005) mengenai kriteria pemilihan media yaitu (1) kesesuaian dengan aspek yang diharapkan, (2) sesuai dengan usia anak, (3) biaya, (4) ketersediaan, dan (5) kualitas media. Kualitas sebuah media juga dilihat dari materi yang dimuatnya.

\subsubsection{Validasi Ahli Media}

Media Lectora Inspire subtema "Indahnya Persatuan dan Kesatuan Negeriku" pembelajaran $3 \& 4$ telah direvisi sesuai dengan saran dan masukan oleh ahli media, yang telah disesuaikan dengan pendapat Wahono, R. S (2006) mengenai kriteria penilaian terhadap media: (1) efektif dan efisien dalam pengembangan ataupun penggoperasian media pembelajaran; (2) reabilitas atau kehandalan media dapat berjalan dengan baik, tidak mudah eror atau berhenti saat pengoperasiaann; (3) mudah dalam dikelola dan memodifikasi; (4) mudah digunakan dan sederhana dalam pengoperasiannya; (5)kompatibel media dapat diinstal atau diperbanyak diberbagai komputer atau laptop; (6) aplikasi Lectora Inspire dapat dimanfaatkan kembali untuk mengembangkan mata pelajaran lain. 
Validasi ahli media meliputi penilaian indikator penyajian memperoleh presentase sebesar $100 \%$, indikator kepraktisan memperoleh presentase sebesar $75 \%$, dan indikator kemenarikan memperoleh presentase sebesar 100\%. dengan kesimpulan dari ketiga tersebut didapatkan rata-rata sebesar 91,6\%. Berdasarkan kriteria yang diadaptasi dari Akbar (2015: 82) maka dalam interval $85,01 \%-100,00 \%$. Hasil ini sudah lebih baik, melihat sebelumnya, Sukamto \& Wardani (2016: 27) mengembangkan media pembelajaran Lectora Inspire muatan matematika hanya tervalidasi $82,5 \%$ dari ahli media.

Ahli media memberikan saran untuk tombol dalam media sebaiknya konsisten tidak berubah-ubah, tombol dipastikan mudah ditemukan pengguna, kemudian memperbaiki tampilan slide hasil evaluasi dan menambahkan tombol menu dan keluar agar tidak membingungkan pengguna. Hal ini disesuaikan dengan pendapat Nurdyansyah \& Widodo (dalam Nurdyansyah dan Riananda Luly, 2015: 104), dampak positif dari penggunaan teknologi dalam pembelajaran antara lain: (a) memudahkan siswa dalam belajar, dikarenakan siswa lebih suka praktek dari pada teori; (b) siswa lebih mudah memahami materi yang disampaikan menggunakan media komputer, (c) pembelajaran menjadi lenih menarik karena media dapat memunculkan gambar, suara sehingga siswa lebih bersemangat dalam belajar; (d) memudahkan siswa maupun guru dalam mencari sumber yang tidak ada dalam buku pelajaran.

\subsubsection{Validasi dan Revisi Pengguna (Guru)}

Validasi pengguna adalah guru kelas kelas IVB SDN Karangtengah 1 Kota Blitar, adapun aspek penilaian meliputi aspek kelayakan isi materi, penyajian materi, bahasa, dan penyajian desain. Validasi dari pengguna ini mendapatkan nilai 94,4\%. Persentase penilaian ini masuk ke dalam rentang $85,01 \%$ - 100,00\%, jika diinterpretasikan maka hasilnya sudah sangat valid, tidak memerlukan revisi lagi ketika digunakan. Penilaian kevalidan dari pengguna ini sudah baik melihat ketika Astuti (2018) mengembangkan media Lectora Inspire pada Tema 1 Subtema 1 Pembelajaran 4, hanya tervalidasi 4,3 atau $90 \%$ dari pengguna (guru). Pengguna juga memberikan masukan terhadap media Lectora Inspire yaitu keterkaitan antara tampilan gambar dan video sehingga menarik perhatian siswa dan dapat menjadi media yang memberikan manfaat terhadap proses pembelajaran sehingga belajar lebih bermakna.

Hal ini sejalan dengan pendapat Muhson (2010) manfaat media pembelajaran secara praktis, antara lain: (a) mengkonkretkan konsep-konsep yang bersifat abstrak, sehingga dapat mengurangi verbalisme (b) membangkitkan motivasi, sehingga dapat memperbesar perhatian individual siswa untuk seluruh anggota kelompok belajar sebab jalannya pelajaran tidak membosankan dan tidak monoton (c) memfungsikan seluruh indera siswa, sehingga kelemahan dalam salah satu indera (misal: mata atau telinga) dapat diimbangi dengan kekuatan indera lainnya; (d) mendekatkan dunia teori/konsep dengan realita yang sukar diperoleh dengan cara-cara lain selain menggunakan media pembelajaran; (e) meningkatkan kemungkinan terjadinya interaksi langsung antara siswa dengan lingkungannya; dan (f) memberikan uniformitas atau keseragaman dalam pengamatan, sebab daya tangkap setiap siswa akan berbeda-beda tergantung dari pengalaman serta intelegensi masing-masing siswa 
Pengguna juga menyarankan agar di semua slide media pembelajaran Lectora Inspire diberikan tombol yang lengkap agar dapat memancing karakter rasa ingin tahu pada diri siswa. Hal tersebut sejalan dengan tujuan peniliti sebagai upaya memupuk rasa ingin tahu siswa yang lebih dalam dan meluas tentang materi keragaman ekonomi.

\subsubsection{Uji Coba Produk}

Uji coba media dilaksanakan dua kali yaitu uji coba lapangan tahap pertama dan uji coba lapangan tahap kedua. Uji coba lapangan tahap pertama dilakukan di kelas IVA SDN Karangtengah 1, sedangkan uji coba lapangan tahap kedua dilaksanakan di IVB SDN Karangtengah 1. Adapun data hasil validasi disajikan dalam tabel dibawah.

Tabel 4. Persentase Hasil Uji Coba Media

\begin{tabular}{llll}
\hline No & Validator & Persentase & Kriteria \\
\hline 1. & Uji coba lapangan tahap pertama & $98,3 \%$ & Sangat praktis, menarik dan \\
2. & Uji coba lapangan tahap kedua & $93,3 \%$ & dapat menguatkan karakter \\
Rata-rata & $95,8 \%$ & rasa ingin tahu siswa \\
\hline
\end{tabular}

\subsubsection{Uji Coba Lapangan Tahap Pertama}

Uji coba media adalah uji yang dilakukan terhadap media yang telah direvisi berdasarkan hasil validasi ahli materi, ahli media, dan pengguna. Uji coba media dilakukan dengan melibatkan 6 siswa kelas 5A SDN Karangtengah 1, uji coba ini dilakukan untuk mengetahui keparktisan, kemenarikan dengan pengutan karakter rasa ingin tahu media berdasarkan penilaian siswa. Uji coba lapangan tahap pertama dilakukan untuk meminimalisir kesalahan sebelum dilakukan uji coba lapangan tahap kedua. Hasil penilaian uji coba lapangan tahap pertama menyatakan tingkat kepraktisan, kemenarikan dengan pengutan karakter rasa ingin tahu siswa sebesar 95,8 \%, artinya bila diinterpretasi masuk ke dalam rentang $76 \leq \mathrm{P} \leq$ 100, menyatakan produk sangat praktis, dan dapat digunakan tanpa revisi. Respons siswa terhadap media Lectora Inspire sangat positif. Siswa setuju bahwa (a) media Lectora Inspire sangat menarik; (b) mudah digunakan; (c) mudah untuk memahami materi; (d) dapat mengurangi rasa jenuh dan bosan; (e) gambar, teks, animasi dan video bagus; (f) dapat menambah pengetahuan; (g) tertarik dalam hal baru; (h) meningkatkan bertanya jawab dengan guru; (i) tanpa bantuan guru; dan (j) dapat mendorong belajar lebih lanjut.

\subsubsection{Uji Coba Lapangan Tahap Kedua}

Uji coba lapangan tahap kedua dilakukan setelah media mengalami penyempurnaan sesuai uji lapangan tahap pertama. Hasil dari uji coba lapangan tahap kedua mendapat nilai kepraktisan, kemenarikan dengan pengutan karakter rasa ingin tahu media 93,3\%, artinya bila diinterpretasi masuk ke dalam rentang $76 \leq \mathrm{P} \leq 100$, menyatakan produk sangat praktis, dan dapat digunakan tanpa revisi. Bedasarkan hasil uji coba siswa setuju bahwa (a) media Lectora Inspire sangat menarik; (b) mudah digunakan; (c) mudah untuk memahami materi; (d) dapat mengurangi rasa jenuh dan bosan; (e) gambar, teks, animasi dan video bagus; (f) dapat menambah pengetahuan; (g) tertarik dalam hal baru; (h) meningkatkan bertanya jawab dengan guru; (i) tanpa bantuan guru; dan (j) dapat mendorong belajar lebih lanjut. Namun 
hanya ada satu siswa yang tidak setuju dengan semua pernyataan diatas dan ada beberapa siswa tidak setuju dengan pernyataan penggunaan media tanpa bantuan guru.

Media Lectora Inspire sendiri dapat menguatkan rasa ingin tahu pada siswa, hal ini dapat dilihat saat siswa berantusias dalam membaca materi yang ada didalam monitor dan selalu ingin belajar lebih lanjut dengan dibuktikan siswa menekan tombol-tombol yang didalamnya berisi materi, gambar, video beserta contoh-contohnya. Selain itu siswa juga aktif mengajukan pertanyaan mengenai materi kemudian siswa mencatat hasil temuan yang didapat kemudian dibacakan didepan kelas. Sesuai dengan pendapat Ameliah dalam (Fauzi dkk 2018: 30) rasa ingin tahu dapat dilihat dengan munculnya perilaku siswa berupa (1) menggunakan beberapa alat indera untuk menyelidiki objek dan peristiwa; (2) mengajukan pertanyaan tentang objek dan peristiwa; (3) memperlihatkan minat pada hasil percobaan. Dengan demikian, Media Lectora Inspire dapat membuat siswa lebih mengetahui hal-hal baru dan memudahkan dalam siswa dalam menemukan informasi.

\section{Simpulan}

Penelitian dan pengembangan produk media pembelajaran Lectora Inspire materi keragaman ekonomi di Indonesia telah di validasi oleh ahli materi, ahli media, dan pengguna/guru. Hasil validasi ahli materi memperoleh sebesar 91,6\%, validasi ahli media memperoleh sebesar 91,6\%, dan validasi pengguna/ guru memperoleh presentase sebesar 94,4\%. Disamping itu hasil angket uji coba tahap pertama memperoleh presentase sebesar 98,3\%, sedangkan hasil uji coba tahap kedua memperoleh presentase sebesar 93,3\%, Setelah melalui proses pengerjaan, validasi, dan uji coba dapat diketahui bahwa media pembelajaran Lectora Inspire termasuk dalam kategori valid, praktis, dan menarik dengan pengutan karakter rasa ingin tahu.

\section{Daftar Rujukan}

Akbar, S. (2015). Instrumen Perangkat Pembelajaran. Bandung: PT. Remaja Rosda Karya.

Astuti, R. (2018). Pengembangan Media Pembelajaran Berbasis Lectora Inspire Mengacu Pada Kurikulum 2013 Tema 1 Subtema 1 Pembelajaran 4 Kelas 4 SD. Yogyakarta.

Fauzi, A. (2018). Penguatan Karakter Rasa Ingin Tahu Dan Peduli Sosial Melalui Discovery Learning. Jurnal Teori dan Praksis Pembelajaran IPS, 2(2), 83-93.

Mas'ud, M. (2014). Membuat Multimedia Pembelajaran Dengan Lectora Inspire. Yogyakarta: Pustaka Shonif.

Muhson, A. (2010). Pengembangan Media Pembelajaran Berbasis Teknologi Informasi. Jurnal Pendidikan Akuntansi Indonesia. 8 (2).

Nurdyansyah, N. \& Rianand, L. (2016). Developing ICT-Based Learning Model to Improve Learning Outcomes IPA of SD Fish Market in Sidoarjo. Jurnal TEKPEN, 1(2).

Santoso, K. S. (2016). Pengembangan Multimedia Interaktif Perubahan dan Pelestarian Lingkungan Berbasis Pendekatan Ilmiah Untuk Siswa Kelas X SMA Negeri 1 Lawang. SKRIPSI Jurusan Biologi-Fakultas MIPAUM.

Setyosari, P. \& Sikhabuden. (2005). Media Pembelajaran. Malang: Elang Emas.

Shalikhah, N. D. (2017). Media Pembelajaran Interaktif Lectora Inspire Sebagai Inovasi Pembelajaran. Warta $L P M, 20(1), 9-16$.

Siska, Y. (2016). Konsep Dasar IPS untuk SD/MI. Yogyakarta: Garudhawaca.

Sugiyono. (2015). Metode Penelitian Pendidikan. Bandung: Alfabeta. 
Jurnal Pembelajaran, Bimbingan, dan Pengelolaan Pendidikan, 1(3), 2021, 213-224

Sukamto, S., \& Wardani, A. K. (2016). Pembelajaran Matematika Menggunakan CD Interaktif Amt Berbasis Lectora Inspire Untuk Siswa SD. Mimbar Sekolah Dasar, 3(1), 19-28.

Wahono, R. S. (2006). Aspek Dan Kriteria Penilaian Media Pembelajaran. 